\title{
DIGITIZATION OF CULTURAL HERITAGE OF SLOVAK REPUBLIC
}

\author{
J. Brehovská ${ }^{\mathrm{a}}$, P. Brunčák ${ }^{\mathrm{a}}$, L. Dedík ${ }^{\mathrm{b}}$, I. Kravjanská ${ }^{\mathrm{a}}$, A. Sučíková ${ }^{\mathrm{a}}$ \\ ${ }^{a}$ The Monuments Board of the Slovak Republic, Bratislava, Slovak Republic - (Jana.Brehovska, Peter.Bruncak, Ivica.Kravjanska, \\ Anna.Sucikova)@pamiatky.gov.sk \\ ${ }^{\mathrm{b}}$ STUDIO 727, Bratislava, Slovak Republic-laco@727.sk
}

Commission V, WG V/2

KEY WORDS: cultural heritage, terrestrial laser scanning, digital photogrammetry

\begin{abstract}
:
The Monuments Board of the Slovak Republic within the Operational Programme Information Society from 2012, is digital documenting selected national cultural monuments of the Slovak Republic. Within this project 1,855 architectural objects in Slovakia has been digitized by internal component of the The Monuments Board SR and external suppliers. For measurement there were used the most modern surveying technologies - digital photogrammetry (DP) of land and aerial images and terrestrial laser scanning (TLS). The outputs of digitization are point cloud, highly detailed polygon models, orthoimages, gigapixel images and $2 \mathrm{D}$ drawing documentations. During the project, arose the need to process the huge number of images (thousands or tens of thousands) and also need a TLS connection to DP. For this reason, started Slovak commercial firm developing of new software which enable this processing and connection. The outcomes are unique spatial models of large architectural complexes (castles, monasteries, churches...) with high detail and accuracy up to $1 \mathrm{~cm}$. Article is devoted to the project description and the method of digitization for the specific types of the cultural monuments.
\end{abstract}

\section{INTRODUCTION}

The Slovak national project Digital Monuments Fund (DMF) funded by the Operational Programme Information Society (OPIS) lasted between 2012 and 2015. This project covers The Monument Board of the Slovak Republic (MBSR) and is implemented under Priority Axis 2 Development of repository institutions and modernization of their national infrastructure (Škoviera, L., 2012).

The aim of this project is to improve the system of acquisition and processing of data about the cultural heritage of the Slovak Republic (SR) and the subsequent use of digital content for the purpose of protecting the cultural heritage values of objects SR.

Planed number of digitalized objects was 1,855 . For digitalization there were used data collection methods such as terrestrial laser scanning (TLS), digital photogrammetry (DP), photography by UAV technology, conventional surveying technology and global navigation satellite systems (GNSS).

The output of the digitization process is the spatial point cloud, 3D models, orthoimages, drawings, videos and photographs. This paper describes the process of data collection in the field, processing of measured data in diversified softwares and presents the results of digitization applicable in historic preservation.

\section{DIGITAL MONUMENTS FUND}

The process of digitizing the cultural heritage of the SR was realized in 2 ways - by external suppliers and by internal component of the MBSR. The task of both components together was digitization of 1,855 selected objects of the cultural heritage. These objects can be part of larger heritage groups (e.g. heritage group Church with areal in Ladomirová consist of 4 historical objects - church alone, belfry, fortification and entrance gate). The overview of the object variousness and number of types is shown in the Table 1.

\begin{tabular}{|l|c|c|}
\hline Types of the heritage groups & $\begin{array}{c}\text { Heritage } \\
\text { groups }\end{array}$ & $\begin{array}{c}\text { Historical } \\
\text { objects }\end{array}$ \\
\hline Castles and castle ruins & 46 & 833 \\
Churches & 59 & 106 \\
Folk and burgess architecture & 30 & 56 \\
Mansions & 6 & 76 \\
Monasteries & 5 & 45 \\
Memorials & 4 & 12 \\
Historical town reserves & 3 & 394 \\
Mills & 3 & 6 \\
Bridges & 2 & 3 \\
Cementery areas & 5 & 206 \\
Archeological sites & 5 & 6 \\
Altars and Iconostasis & 6 & 28 \\
Other groups & 11 & 84 \\
Together & 185 & 1,855 \\
\hline
\end{tabular}

Table 1. Overview of digitalized object types

The digitization of large objects and larger sites where it also UAV technology was needed, ensures external contractor STUDIO 727. The documenting of smaller structures with the emphasis on precision drawings was realized by Department of digitization and graphic documentation MBSR.

Selected monuments Fund of SR was digitalized by several geodetic methods, which were selected based on the specific features of each object. All spatial data of objects are located in the uniform coordinate system. This allows the virtual tour on the Slovakia map e.g. in Bentley application GeoWeb Publisher. Digitized national monuments will be used mainly for the needs of the MBSR, restorers, historians or for educational purposes. 
They also find use for lay public (e.g. in cinematography or computer games).

\subsection{The internal digitalization}

The internal component MBSR - Department of digitization and graphic documentation (DDGD) is a specialized institution, which was created for the needs of the project, based on an existing Department of Graphic documentation. Thanks to the project, the department purchased modern surveying equipment, there was set up a new server room with a large repository and high-end computing workplace. DDGD mostly used 3 modern surveying methods: TLS, DF and an optical 3D scanning.

The main method of digitization has been TLS. This method has proven to be highly reliable and has been used for monochromatic texture objects, the larger and more qualified objects. MBSR has a laser scanner Riegl VZ-400 with removable camera Nikon D700, which provides high-quality textures. Scanner parameters are shown in Table 2.

\begin{tabular}{|l|c|c|}
\hline Riegl VZ-400 & $\begin{array}{c}\text { High speed } \\
\text { mode }\end{array}$ & $\begin{array}{c}\text { Long range } \\
\text { mode }\end{array}$ \\
\hline Scan rate & $\begin{array}{c}122,000 / \mathrm{sec} \\
350 \mathrm{~m}\end{array}$ & $\begin{array}{c}42,000 / \mathrm{sec} \\
600 \mathrm{~m}\end{array}$ \\
Maximum range & \multicolumn{2}{|c|}{$0.5 \mathrm{~m}$} \\
Minimum range & $5 \mathrm{~mm}$ \\
Accuracy & $360^{\circ} \times 100^{\circ}$ \\
Field of view - horizontal x vertical & \multicolumn{2}{|c|}{$9.6 \mathrm{~kg}$} \\
Weight & \\
\hline
\end{tabular}

Table 2. Riegl VZ-400 parameters

The processing operation was implemented in software RiSCAN PRO delivered by the scanner manufacturer. The output is a pointcloud, which was subsequently processed into a 3D model in the software Geomagic Studio or directly from the pointclouds were made drawings in the program MicroStation V8i with extension Descartes.

DP was used mainly for digitizing smaller objects with polychromatic texture, murals, altars and iconostasis, or for fulfilment of objects details measured by TLS. MBSR currently uses medium format camera PhaseOne with a resolution of digital back $80 \mathrm{Mpx}$.

The image processing was carried out in softwares PhotoScan or PhotoModeler (Trhan, O., Fraštia, M., 2014). The images were oriented and from them was created pointcloud and polygonal 3D models. Subsequently, highly detailed, fully textured and georeferenced orthoimages were created. From the pointclouds or orthoimages were made detailed technical drawings in a similar way as for TLS.

The optical 3D scanning was used for the documentation of cultural objects or their small parts, where the high precision was required to achieve (Marčiš, M., Fraštia, M., Brunčák, P., 2013). In the project there was purchased 3D scanner Comet L3D 5M from Steinbichler.

The task of DDGD was the measuring of 400 historical objects. They consist of very various types and sizes. The largest group of digitized objects represented:

1. Sacral objects - churches, belfries, altars, iconostasis, baptimal fonts

2. Folk and burgess houses - knocker, wooden and stone houses

\section{Technical objects - bridges, mills, tug}

Among other things there were measured also various archaeological sites, areas of cemeteries and small movable objects.

During the project there were by internal part taken more than 110,000 pictures and more than 3,000 scan positions.

2.1.1 Digitalization of sacral objects: An example of documentation of historic sacral objects is measuring of Church of saint Martin in Čerín (Figure 3.) This church is an early Gothic one nave church built in the 14th century. Inside the church there are preserved Gothic wall paintings.

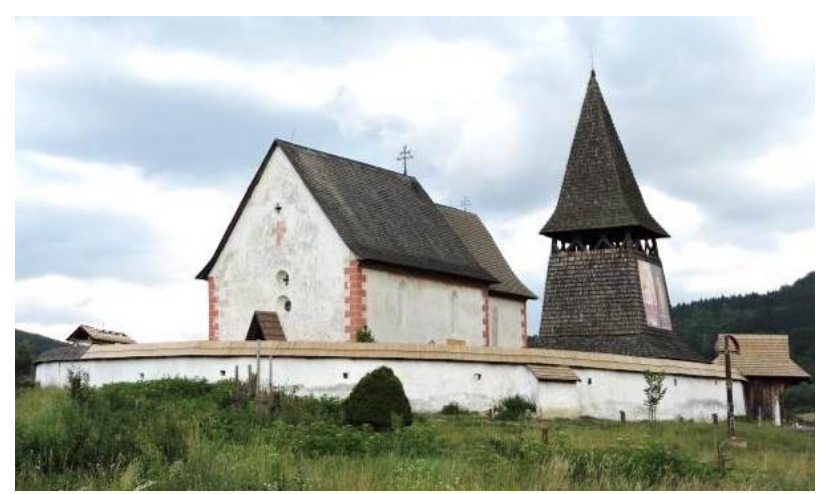

Figure 3. Picture of the church in Čerín

Architecture of the church was targeted by the TLS, details of measuring are shown in the Table 4 . The histogram of residues after the scan registration is illustrated in Figure 5.

\begin{tabular}{|l|c|c|c|}
\hline $\begin{array}{l}\text { Part of } \\
\text { object }\end{array}$ & $\begin{array}{c}\text { Duration of the } \\
\text { measurement }\end{array}$ & $\begin{array}{c}\text { Number of } \\
\text { scanner } \\
\text { positions }\end{array}$ & $\begin{array}{c}\text { Standard deviation } \\
\text { of scans } \\
\text { registration }\end{array}$ \\
\hline exterior & hours & 28 & $\mathrm{~mm}$ \\
interior & 8 & 16 & 3.5 \\
\hline
\end{tabular}

Table 4. Details of measuring
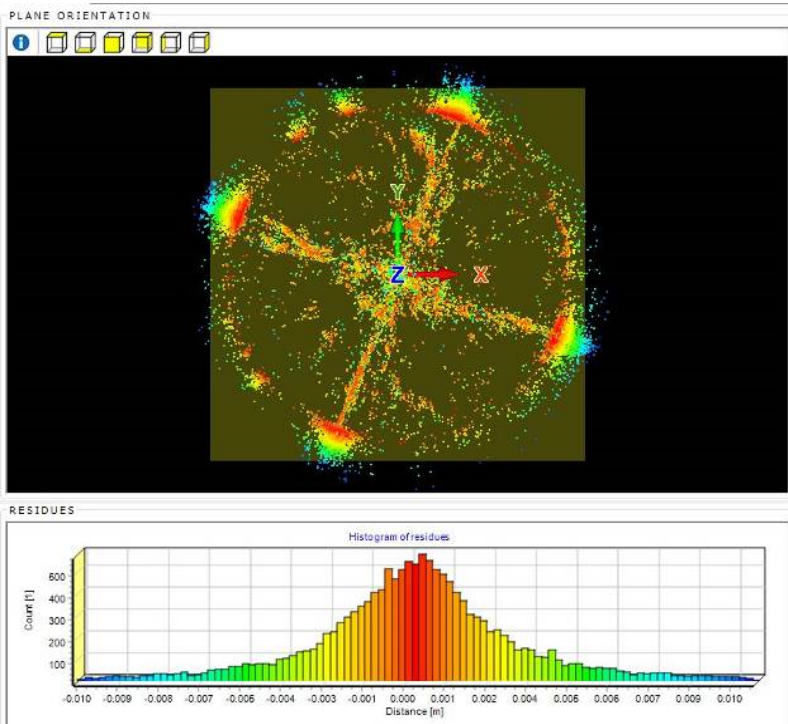

Figure 5. Histogram of residues 
Valuable Gothic frescoes have been documented with DP. There were taken 112 pictures and the standard deviation of model registration to the global coordinate system is $3.0 \mathrm{~mm}$.

From all obtained data was created polygonal model, vector model and completed technical documentation of church (Figure 6. and 7.).
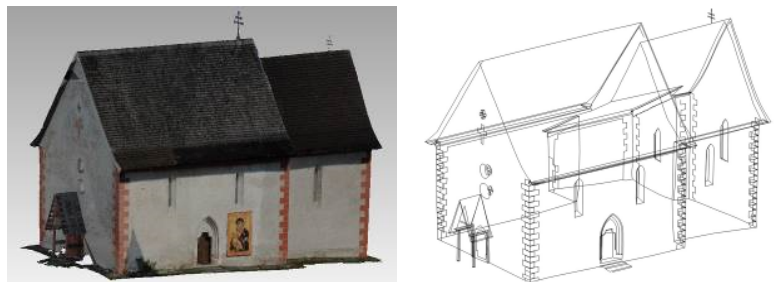

Figure 6. Polygonal and vector model of the church in Čerín

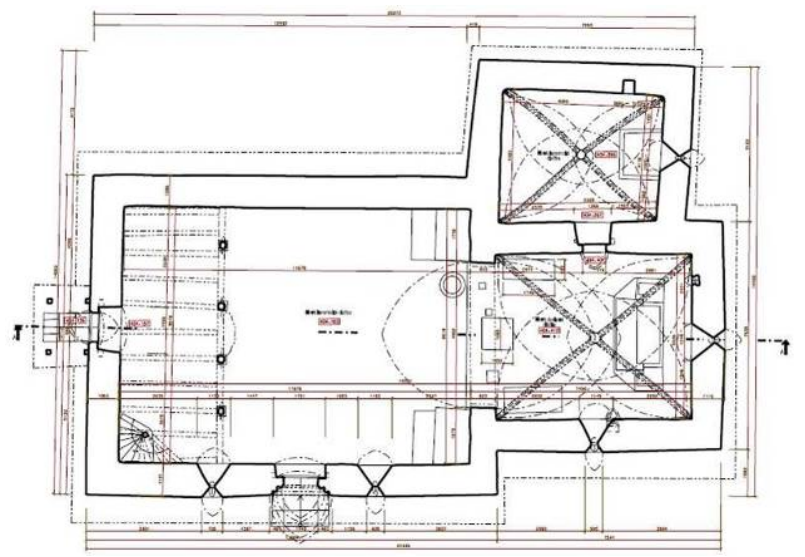

Figure 7. Ground plan section of the church in Čerín

2.1.2 Digitalization of folk and burgess houses: An example of historic documentation of burgess houses by TLS method is measurement of knocker in Banská Štiavnica (Figure 8). This is a four stage structure with rafters and a tower. Details of measuring are shown in the Table 9.

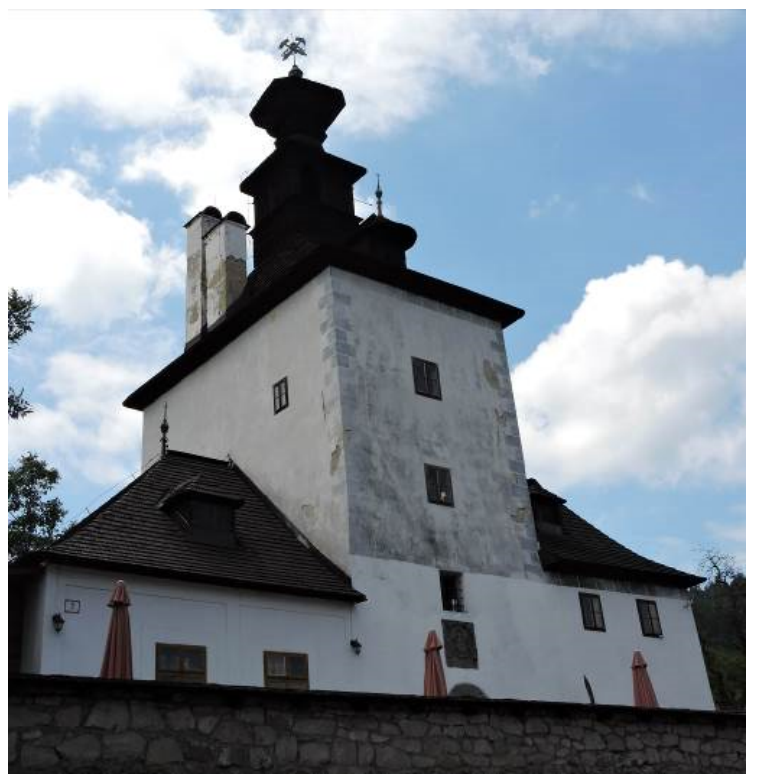

Figure 8. Picture of the Knocker in Banská Štiavnica

\begin{tabular}{|l|c|c|c|}
\hline $\begin{array}{l}\text { Part of } \\
\text { object }\end{array}$ & $\begin{array}{c}\text { Duration of the } \\
\text { measurement }\end{array}$ & $\begin{array}{c}\text { Number of } \\
\text { scanner } \\
\text { positions }\end{array}$ & $\begin{array}{c}\text { Standard deviation } \\
\text { of scans } \\
\text { registration }\end{array}$ \\
\hline exterior & 9 & 20 & $\mathrm{~mm}$ \\
interior & 11 & 36 & 3.8 \\
\hline
\end{tabular}

Table 9. Details of measuring

From all obtained data was created polygonal model, vector model and completed technical documentation of the knocker (Figure 10. and 11.).

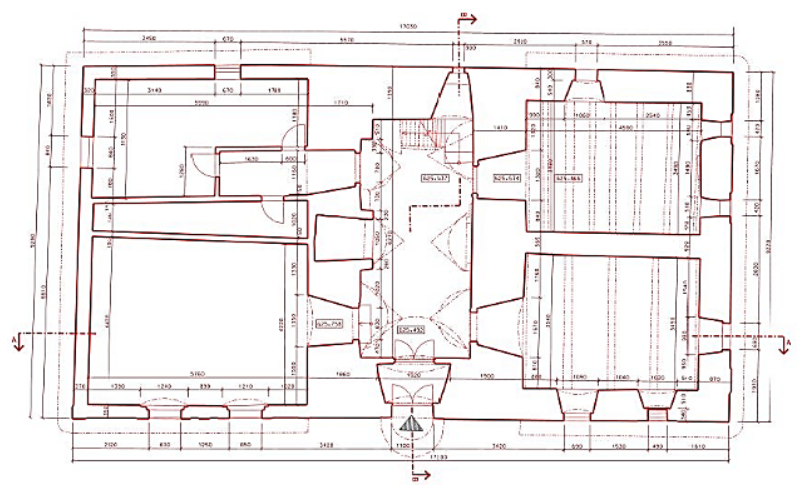

Figure 10. Ground plan section of the knocker

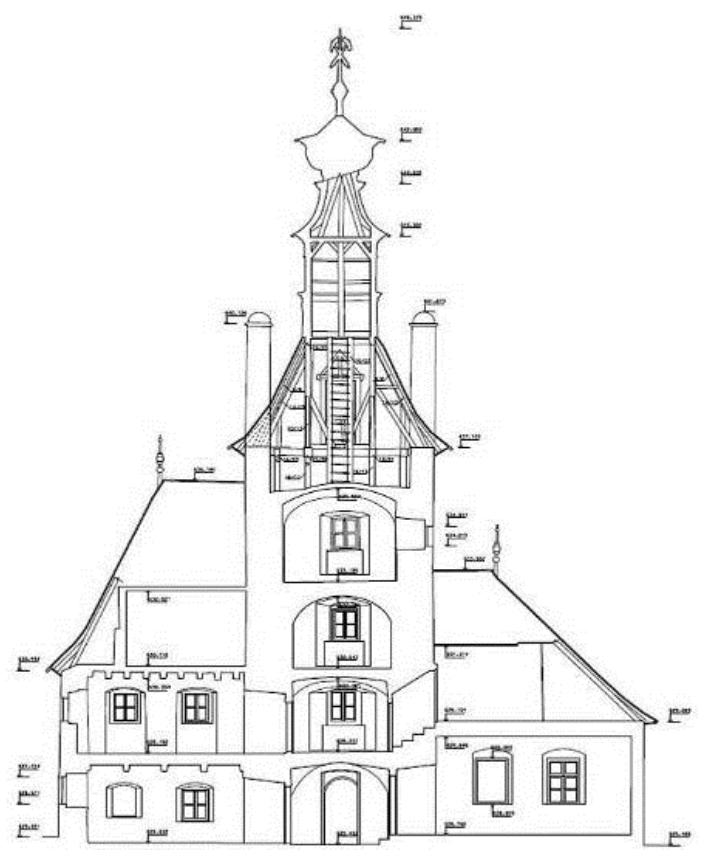

Figure 11. Longitudinal section view of the knocker

2.1.3 Digitalization of technical objects: An example of historic documentation of technical objects is the measuring of the bridge from 1904 in Král'ová at Senec. The field measuring of the bridge took one day, there were selected 11 positions of scanner. The standard deviation of the scans registration to the global coordinate system is $3.3 \mathrm{~mm}$ (Haličková, J., Brunčák, P., Sučíková, A., 2014). Both of bridge frontages have been documented with DP. There were taken 123 pictures and the standard deviation of model registration to the global coordinate system is $3.1 \mathrm{~mm}$. An example of the obtained results are in Figures 12., 13. and 14. 


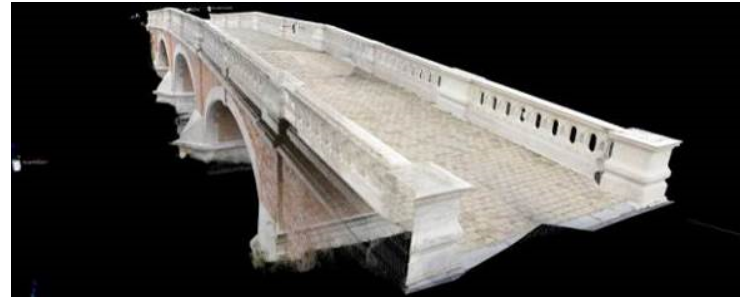

Figure 12. Registered pointclouds of the bridge

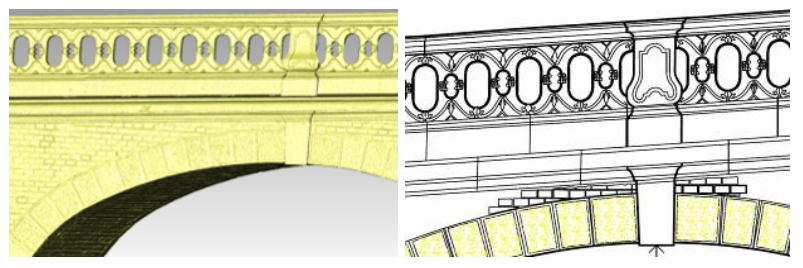

Figure 13. Detail of the polygonal model and the vector model

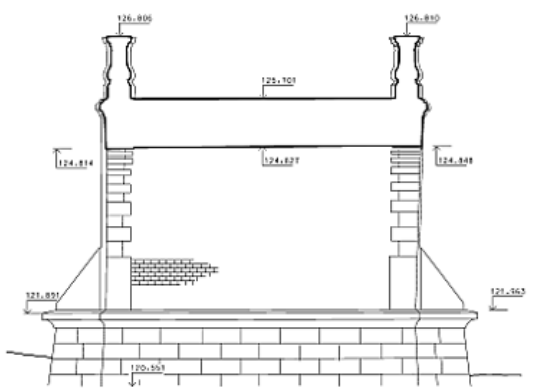

Figure 14. Cross section view of the bridge

2.1.4 Digitalization of technical objects: One of the most interesting objects that have been digitized by internal digitalization is diptych travel sundial with compass (Figure 15). The sundial was found at Uhrovec castle and the finding was dated by analogies in the second half of 16th century. It was made from animal bone using sculptured decorations and metal applications. In Slovakia there are known discoveries of another diptych sundial at Ilija and Svodín. Specimen from Uhrovec is the oldest and best preserved (Horanský, P., Jaššo, F., 2012). The largest dimension of diptych sundial does not exceed $5 \mathrm{~cm}$, so object was digitized by method of optical 3D scanning (Fraštia, M., Brunčák, P., Chlepková, M., 2013).
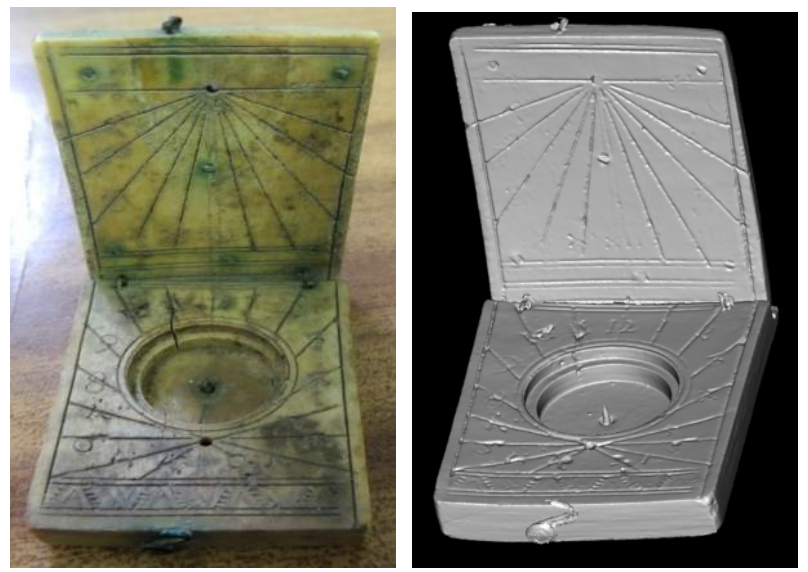

Figure 15. Picture and 3D model of the diptych travel sundial

\subsection{The external digitalization}

External digitalization of historic buildings and urban conservation was secured by the company STUDIO 727 in cooperation with other contractors.

Their task was the measuring of 81 large heritage groups (these groups include 1,457 historical objects). They can be divided into the next categories:

1. Small objects - these were mostly small churches, castle ruins or simple memorials

2. Midsize objects - here were bigger castles and manor houses

3. Large objects - historical town areas

External partner of the digitalization mostly used following modern surveying methods - photogrammetry, laser scanning and combination of these methods in a new software Reality Capture created during the project of digitalization.

During the project there were taken more than $2,000,000$ pictures from the land, more than 100,000 elevation pictures (mainly from the drone and helicopters) and more than 18,000 scan positions.

2.2.1 Digitalization methods: Initial digitalization of each object was realized by laser scanning method. There was used laser scanner Leica ScanStation P20. Scanner parameters are shown in Table 16.

\begin{tabular}{|l|c|}
\hline Leica ScanStation P20 & \\
\hline Scan rate & Up to $1,000,000 / \mathrm{sec}$ \\
Maximum range & Up to $120 \mathrm{~m}$ \\
Minimum range & $0.4 \mathrm{~m}$ \\
Accuracy & $3 \mathrm{~mm} / 50 \mathrm{~m} ; 6 \mathrm{~mm} / 100 \mathrm{~m}$ \\
Field of view - horizontal x vertical & $360^{\circ} \times 270^{\circ}$ \\
Weight & $11.9 \mathrm{~kg}$ \\
\hline
\end{tabular}

Table 16. Leica ScanStation P20 parameters

TLS allows to obtain a digital representation of the objects with high metric precision in a relatively short time. Despite the high metric accuracy the disadvantage of TLS is insufficient level of the detail to display the various architectural elements (reliefs, statues, and details of windows, doors, chimneys, etc.)

Because of the lower level of the detail results of TLS, digital photogrametry was used for measuring of details and difficult to reach areas. This method can achieve a high degree of detail of the measured object. The disadvantage of this method is possible geometry deformation of the object. For this reason it was used only for the measurement of detailed parts of objects.

For photogrammetry there were used multiple cameras. The highest quality camera deployed in digitization of cultural heritage was medium format camera PhaseOne with digital back $80 \mathrm{Mpx}$. In conjunction with Carl-Zeiss optics it offers the highest degree of detail. Its disadvantage is the relatively low speed and weight. The most commonly used cameras were DSLR Nikon D800E and Nikon D810. The full frame sensor resolution is $36 \mathrm{Mpx}$. They offer high performance, high degree of detail and high speed for a given application. A small and lightweight camera GoPro with 12-megapixel resolution, was used to capture in cases where there was little space or difficult access. 
The actual procedure for photogrammetry data collection was carried out by two major methods. The first imaging method is realized by using programmable robotic panorama head Rodeon VR Station HD, set on a tripod on which the camera is attached to the axis misalignment nodal point. This method has been called as "robotic imaging with a tripod." The second method of photogrammetric imaging is shooting without a tripod, which can be named as "handheld imaging." The best results were achieved with the combination of these two methods.

The remaining uncovered parts of the object, especially upper parts of the architecture have been imaged by air, either by helicopters or drones.

For digitalization of most objects was used a combination of the two above mentioned methods - TLS and DP. The main reason for the use of the combination of technologies was an effort to use benefits of each method and to eliminate major weaknesses. Photogrammetry is based on photographic shoot, thus has high color fidelity and it is possible to achieve a high degree of detail. Laser scanning can achieve a high metric accuracy $( \pm 3 \mathrm{~mm})$, but the accuracy may not be sufficient to capture the needed greater detail and is not sufficient to capture detailed textures such as murals or paintings (Dedík, L., 2015).

An equally important factor in the decision was the effort to create a unique process and to verify its practical applicability. This approach is unique, because after a comprehensive analysis of existing commercial products, it was found there is no optimal software solution that addressed these issues.

During the project there was established cooperation with CapturingReality software company. This company is dedicated to the development of photogrammetric software. They created a unique software that allows a combination of automated processing photogrammetry and scanned data and can work with huge number of data. An example of use of the software Reality Capture is illustrated in object Sala Terrena situated at the castle Červený Kameň. Sala Terrena is a ground floor room with a rich early Baroque decoration. Figure 17. represented location of scans positions in the Sala Terrena.

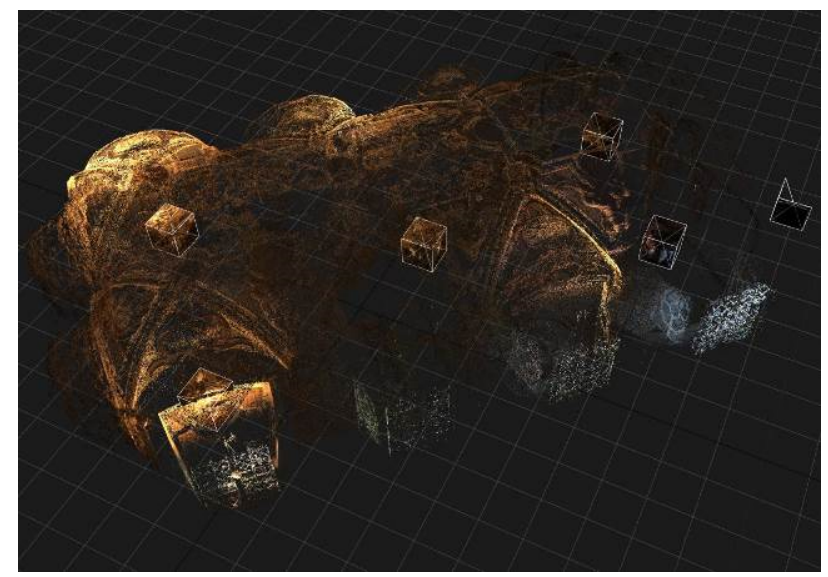

Figure 17. Representation of the scans positions in the Sala Terrena, castle Červený Kameň

Figure 18. represented images positions and obtained pointcloud of Sala Terrena in software background.

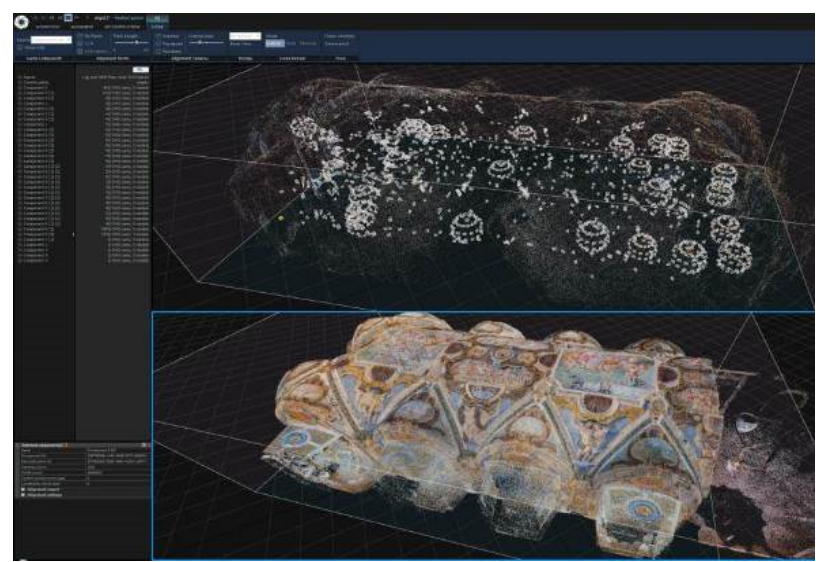

Figure 18. Representation of the images positions (up) and obtained pointcloud (down)

This combination has managed to significantly increase the geometrical and textural accuracy and detail. Comparison of a model obtained only from TLS data with the model of data supplemented by photogrammetric images are shown in Figure 19.

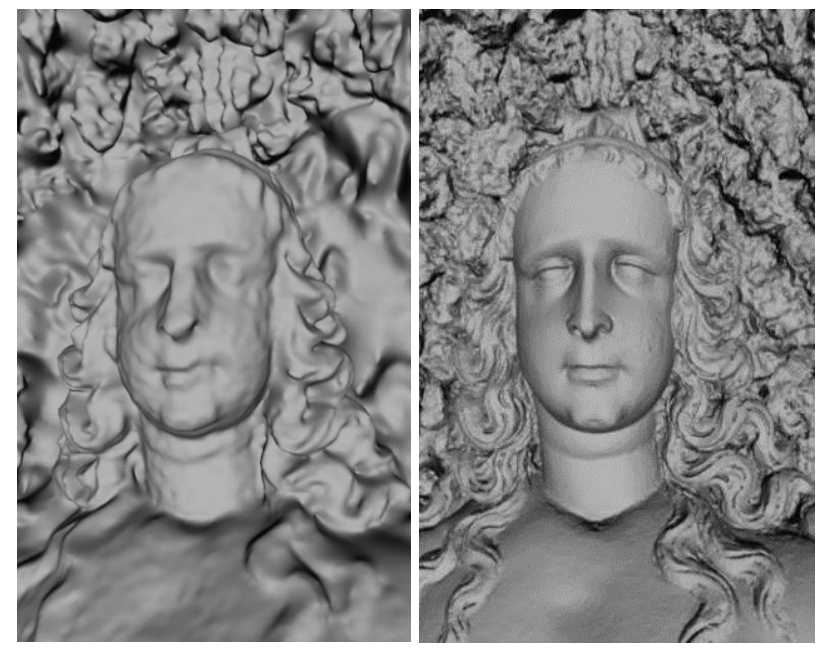

Figure 19. Statue model in Sala Terrena created from TLS data and model after addition of DP data

One of the unique features of used method is the fact that this increase in the rate of detail is (depending on the input) very significant. The final model contained in the photos is up to half the resolution of the real image, the texture information may be maintained practically in the ratio $1: 1$.

During generating textures there was uneven illumination of the object (shadows) eliminated by frequency analysis and other methods, because of achieving a maximally neutral ambient lighting of textures itself (usage of multiple images for each of the texture parts, preference images using the flash with a final multiblending and so). Thus generated mesh with the corresponding texture is the final output of the mode. It allows free movement of the virtual camera in the whole area, maintain its geometry and light-colored features with a high degree of detail and the freedom of creating lighting conditions of the artistic intent, or technical needs (Dedík, L., 2015). Final results are illustrated in Figure 20. and 21. 


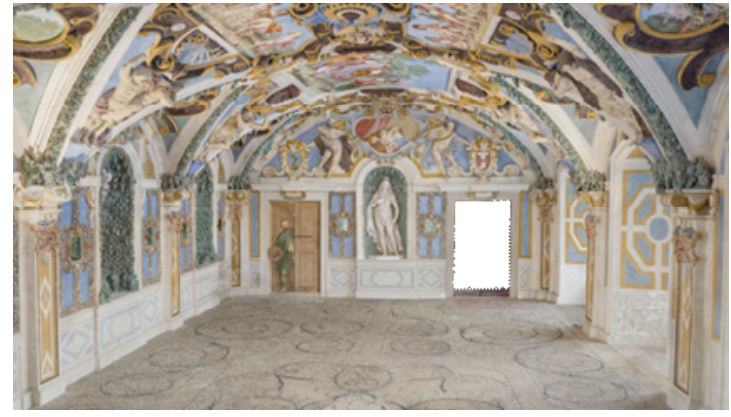

Figure 20. Final textured model of the Sala Terrena

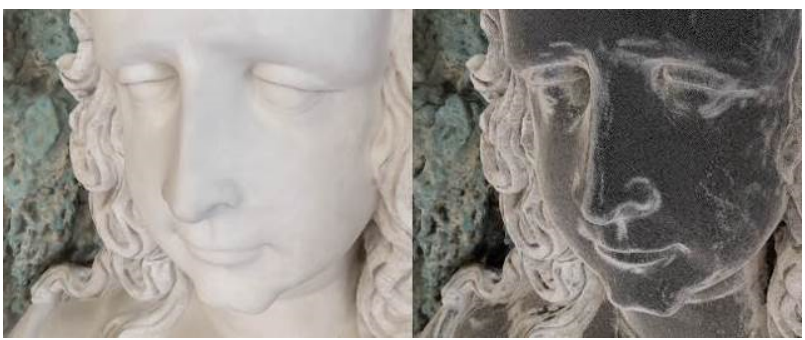

Figure 21. Detail of the statue model represented by textured faces (left) and by edges (right)

2.2.2 Digitalization of small objects: An example of historic documentation of small objects is measurement of the Virgin Mary Assumption Church in Banská Štiavnica (Figure 22. left). It is originally a Romanesque church from the 13 th century, which was later rebuilt in the classical style.

The measurement was carried out in March 2015. Together there were taken 70 scan positions and almost 80,000 pictures. The processing of all these data took more than 1 month. Final model (Figure 22. right) of this object was obtained by combining data from both methods. The part of the interior pointcloud and its model is shown in Figure 23. An example of technical documentation is on Figure 24.
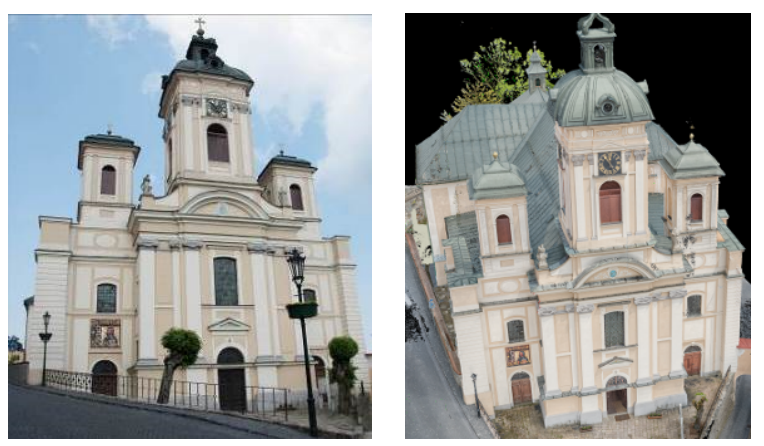

Figure 22. Picture and model of the church

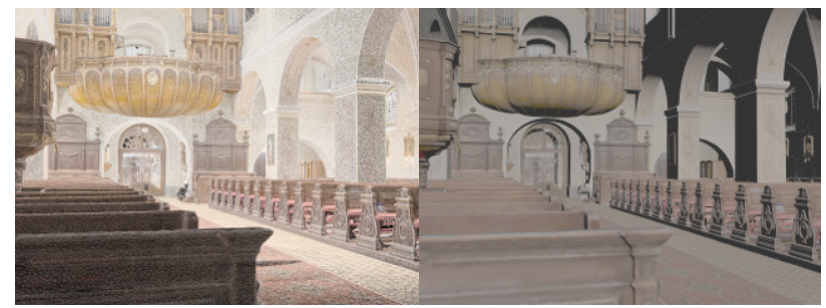

Figure 23. Detail of pointcloud and model of the interior

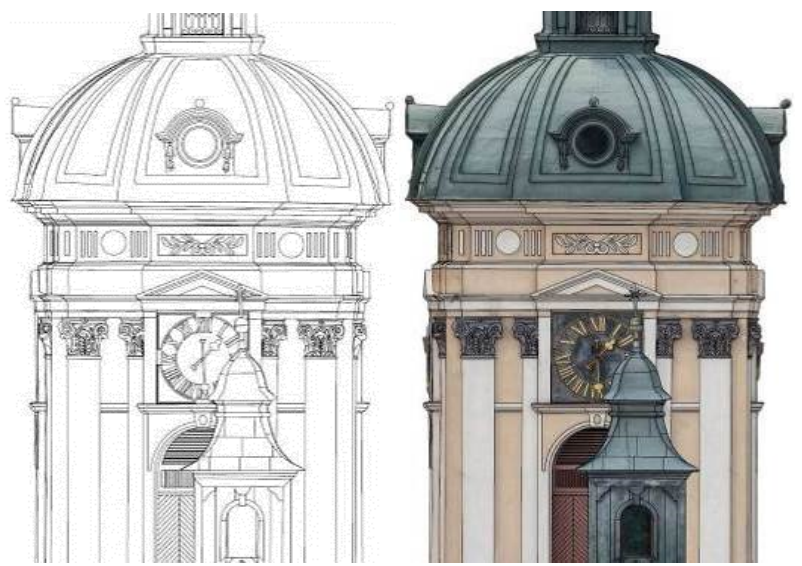

Figure 24. Part of the facade view of the church - drawing and drawing with orthoimage

2.2.3 Digitalization of midsize objects: An example of historic documentation of midsize objects is measurement of the church and chapel in Spišský Štvrtok. This church is a Catholic, Minorite, monastery, Gothic church with Romanesque elements from the 13th century. It was baroquized in 1693 and 1747. To the southern side of the ship there was built Zápol'ský chapel.

The measurement was carried out in September 2014. Together there were taken 150 scan positions and almost 50, 000 pictures. The processing of all these data took more than 4 months. Final model and completed technical documentation (Figure 25., 26.) of this object was obtained by combining data from both methods. Creation of technical documentation in $3 \mathrm{D}$ space is shown in Figure 27.

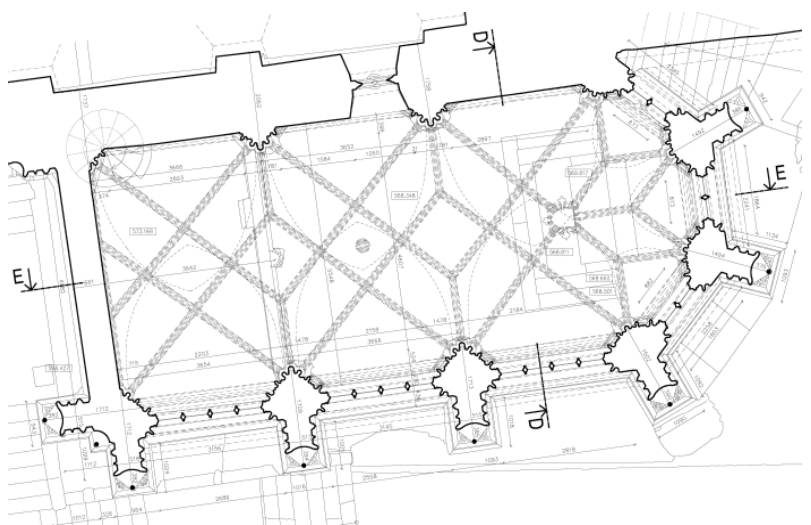

Figure 25. Ground plan section of the Zápol'ský chapel

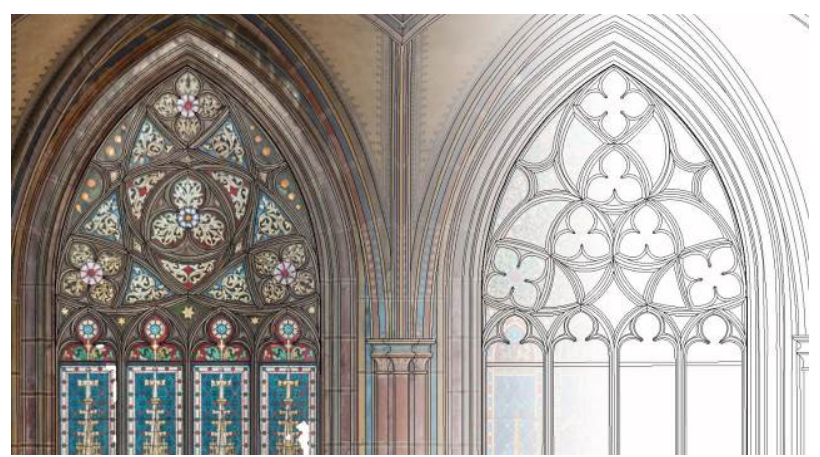

Figure 26. Interior section view of the Zápol'ský chapeldrawing with orthoimage 


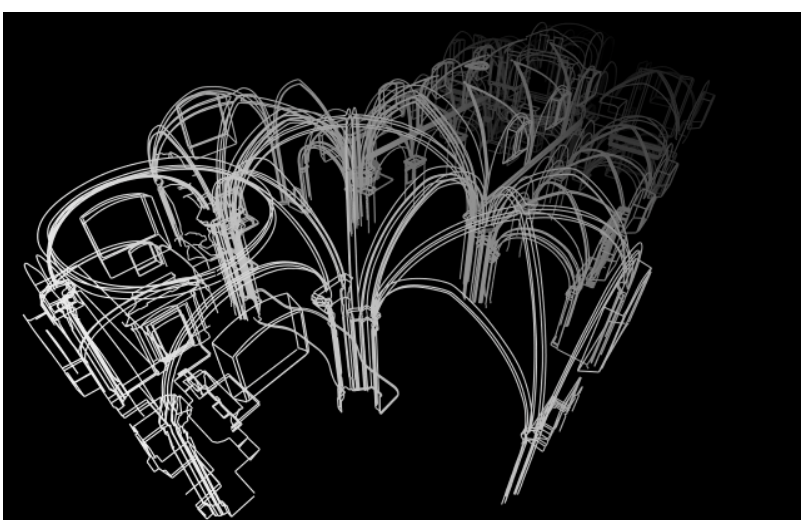

Figure 27. Technical documentation in 3D space

2.2.4 Digitalization of large objects: An example of historic documentation of large objects is digitalization of the historical town reserve Banská Štiavnica. There was captured old town with all building exteriors. Banská Štiavnica is very significant historical mining town. The first mining settlement was founded by Celts in the 3rd century BC. In this reserve there are located many historical buildings, churches and two castles and plenty stoles are under the whole town (Vošková, K., 2010). Very interesting are 24 tajchs (artificial water reservoirs) created by miners to solve "the first energy crisis" of mining. The area of this reserve is about 30 ha.

The measurement was carried out from march to april 2015, when the foliage did not impede. Together there were taken 400 scan positions and almost 400,000 pictures (from land and helicopter). There was also measured Glanzenberg's stole. The processing of all these data took more than 5 months. Part of the obtained pointcloud is in the Figure 28. Final model of this object was obtained by combining data from both methods. This model is shown in Figure 29. and 30.

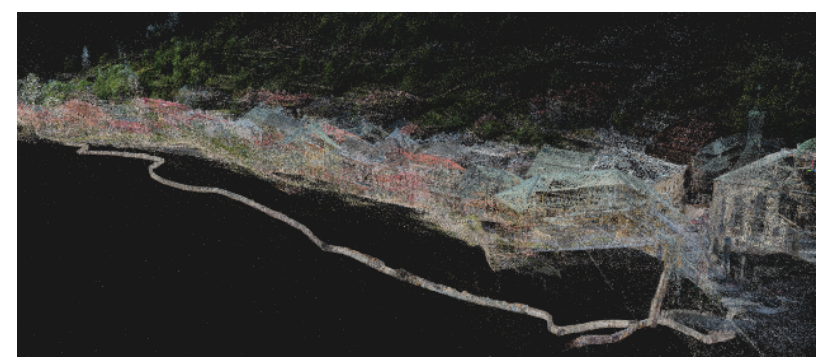

Figure 28. Pointcloud of town reserve with stole Glanzenberg

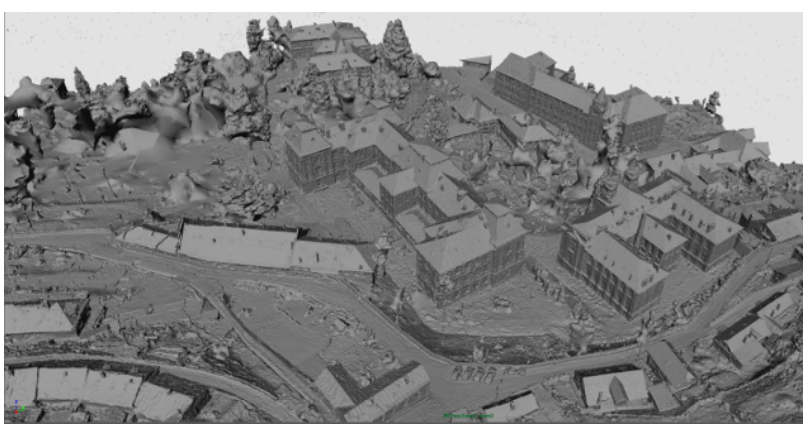

Figure 29. Untextured polygonal model of Banská Štiavnica

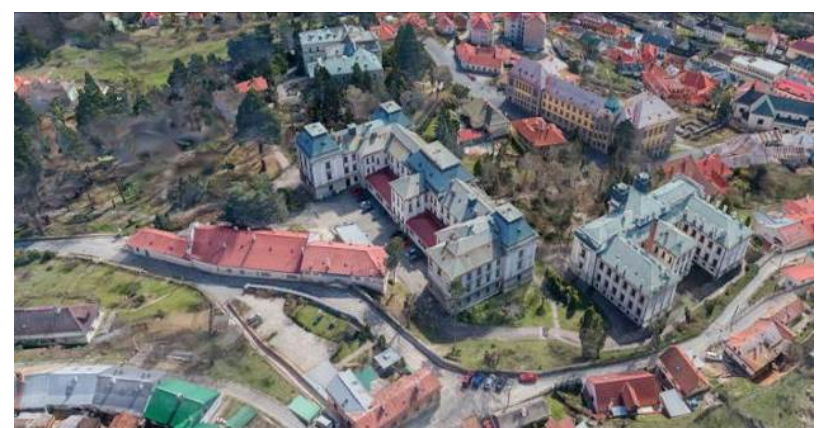

Figure 30. Textured polygonal model of Banská Štiavnica

\section{CONCLUSION}

In this paper, we approached the digitalization of the cultural heritage of the Slovak Republic, we presented documentation of monumental objects and usage of advanced surveying technologies. Each documented object has a characteristic shape, size and texture. That in its specifics applies the most suitable digitizing technology. We applied the most appropriate digitizing technology according to its specifications.

The project aim was as closely as possible record the condition of cultural objects and creates their digital view. The diversity of immovable and movable cultural monuments affected also the variability of the digital outputs. The advantage of new digitalization technologies compared to classical geodetic methods is the speed and detail of data collection in the field. We are able to capture even a surface and color information. The difference occurs in the amount of processing and evaluation of measured data. This requires a specialist approach to digitization and monuments because monumental documentation is compared to standard technical drawings more detailed. Using new methods of surveying is not necessary to pre-define the output documentation because from detailed input data at any time we can make any additional documentation output. Internal and external digitizing team for less than four years managed to document 1,855 objects of cultural heritage in SR. The outputs are stored in the National Cultural Centre and are available to MBSR, a part of them is presented to the general public. In the next 5 years sustainability of the project DMF is planned. The role of the DDGD is to digitize another 500 objects (100 per year). In addition to the project, the private company succeeded in developing the new software Reality Capture, which allows you to process the combined data from laser scanning and digital photogrammetry, so we get a highly detailed and accurate $3 \mathrm{D}$ model also from huge amount of data. This approach is unique till now there was no other software combining both methods.

National cultural monuments are daily degraded by weather conditions and are often damaged and destroyed also by human involvement. Preservation of monuments and presenting all their values is one of the main objectives of their protection, which includes also the digitization of historical monuments. The digitization of monuments provides simplification of research, its detailed documentation in time, provides information background for possible reconstructing damaged or destroyed monuments and last but not least increasing the general awareness of the cultural heritage to the Slovak Republic citizens as well as abroad. 


\section{ACKNOWLEDGEMENTS}

This article was written based on the digital monument fund the project under the Operational Programme Information Society (OPIS) No. 21120120002.

\section{REFERENCES}

Dedík, L., 2015. Tanec $v$ čase. Dissertation thesis, Film and Television Faculty, Academy of Performing Arts Bratislava, p. 90.

Fraštia, M., Brunčák, P., Chlepková, M., 2013. Digitalizácia archeologických artefaktov metódou optického skenovania štruktúrovaným svetlom. In: Počitačová podpora varcheológii. Kočovce, SR, pp. 25-26. ISBN 978-80-223-3396-2.

Haličková, J., Brunčák, P., Sučíková, A., 2014. Využitie metódy terestrického laserového skenovania pri tvorbe pamiatkovej dokumentácie. In: Technológie priestorového modelovania krajiny a objektov - prístupy a aplikácie, Bratislava, SR, Vol. VI. ISBN 978-80-227-4158-3.

Horanský, P., Jaššo, F., 2012. Život na hrade Uhrovec v roku 2012. Monument revue, 1(2), pp. 29-30.

Marčiš, M., Fraštia, M., Brunčák, P., 2013. Optické skenovanie s využitím prirodzených textúr. In: Počitačová podpora $v$ archeológii. Kočovce, SR, pp. 26-27. ISBN 978-80-223-33962.

Trhan, O., Fraštia, M., 2014. Skúsenosti zo spracovania údajov v aplikáciách Photoscan a UAS Master. In: Technológie priestorového modelovania krajiny a objektov - pristupy a aplikácie. Bratislava, SR, pp. 15. ISBN 978-80-227-4158-3.

Škoviera, L., 2012. OPIS - Operačný program Informatizácia spoločnosti. Rozvoj pamätových a fondových inštitúcií a obnova ich národnej infraštruktúry. Národný projekt č. 4 Digitálny pamiatkový fond. In: Pamiatky a múzeá. Bratislava, SR, Vol. 4. pp. 67-68.

Vošková, K., 2010. Mapovanie stavebno - technického stavu historických objektov v Pamiatkovej rezervácii Banská Štiavnica. In: Jesenná škola architektúry 2008-2009. Bratislava, pp. 2829. 